\title{
Methanoculleus palmolei sp. nov., an irregularly coccoid methanogen from an anaerobic digester treating wastewater of a palm oil plant in North-Sumatra, Indonesia
}

\author{
Gerhard Zellner, ${ }^{1}$ Paul Messner, ${ }^{2}$ Josef Winter ${ }^{3}$ and Erko Stackebrandt ${ }^{4}$
}

Author for correspondence: Gerhard Zellner. Tel: +498931872579. Fax: +498931873361.

e-mail: gerhard.zellner (a)gsf.de

1 GSF - Forschungszentrum für Umwelt und Gesundheit, Institut für Hydrologie, Ingolstädter Landstraße 1, D-85764 Neuherberg, Germany

2 Zentrum für Ultrastrukturforschung und Ludwig-BoltzmannInstitut für Molekulare Nanotechnologie, Universität für Bodenkultur, A-1180 Vienna, Austria

3 Institut für Ingenieurbiologie und Biotechnologie des Abwassers, D-76128 Karlsruhe, Germany

4 DSMZ - Deutsche Sammlung von Mikroorganismen und Zellkulturen $\mathrm{GmbH}$, Mascheroder Weg $1 b$, D-38124 Braunschweig, Germany

\begin{abstract}
Strain INSLUZ ${ }^{\top}$ ( = DSM $4273^{\top}$ ) was isolated from a biogas-producing bioreactor treating wastewater of a palm oil mill on North-Sumatra (Indonesia). Cells of strain INSLUZ ${ }^{\top}$ were highly irregularly coccoid, 1.25-2.0 $\mu \mathrm{m}$ in diameter, had a cell envelope consisting of the cytoplasmic membrane and an S-layer of hexagonally arranged glycoprotein subunits with an $M_{r}$ of 120000 , and were flagellated (motility was not observed). Cells were mesophilic and grew most rapidly at $40{ }^{\circ} \mathrm{C}$ on $\mathrm{H}_{2} / \mathrm{CO}_{2}$, formate, 2-propanol/CO ${ }_{2}$, 2-butanol/ $/ \mathrm{CO}_{2}$ and cyclopentanol/ $\mathrm{CO}_{2}$ to give methane. Tungstate promoted growth on $\mathrm{H}_{2} / \mathrm{CO}_{2}$ with acetate as the solely required organic medium supplement. The $\mathrm{G}+\mathrm{C}$ content of DNA was 59 mol \% ( $T_{m}$ method) and 59.5 mol \% (HPLC method). 165 rDNA analysis revealed a phylogenetic relationship to Methanoculleus species; the name Methanoculleus palmolei sp. nov. is therefore proposed for strain INSLUZ' ( = DSM 4273').
\end{abstract}

Keywords: methanogens, Methanoculleus palmolei sp. nov., methanogenic bioreactor, palm oil wastewater treatment, phylogeny

\section{INTRODUCTION}

Irregularly coccoid methanogens occur in various habitats all over the world. However, there are only a few reports on the presence of irregularly coccoid methanogens in wastewater reactors (Zellner \& Winter, 1987a; Schnürer et al., 1994; Zellner et al., 1987, 1989b, 1990, 1991), despite the high diversity of methanogenic subpopulations of anaerobic wastewater reactors (Raskin et al., 1994; Zellner et al., 1997). All irregularly coccoid methanogens isolated from bioreactors belong to the genera Methanoculleus or Methanocorpusculum within two distinct families, the Methanomicrobiaceae and the Methanocorpusculaceae, respectively (Boone \& Xun, 1987;

Abbreviation: PAS stain, periodic acid-Schiff stain.

The EMBL accession number for the 165 rDNA sequence of strain INSLUZ reported in this paper is $Y 16382$.
Ferguson \& Mah, 1983; Maestrojuán et al., 1990; Ollivier et al., 1985, 1986; Xun et al., 1989; Zabel et al., 1985; Zellner et al., 1989b, 1990).

A highly polluting wastewater is produced by palm oil mills which is 100 times more recalcitrant than domestic wastewater. Worldwide, $6.2 \times 10^{6} \mathrm{t}$ palm oil and $15.4 \times 10^{6} \mathrm{t}$ palm oil effluent are produced per annum (Ma \& Ong, 1986). Nothing is known about the microbial populations adapted to the anaerobic treatment of this specific type of wastewater.

In this paper, the isolation and characterization of a hydrogenotrophic, methanogenic strain, strain INSLUZ $^{\mathrm{T}}$, are reported; the strain was isolated from a methanogenic wastewater bioreactor treating palmoil-mill effluent in North-Sumatra (Indonesia). Some characteristics of the secondary alcohol dehydrogenase activity of the unclassified strain INSLUZ ${ }^{\mathrm{T}}$ have been described previously (Bleicher et al., 1989). Features of 
strain INSLUZ ${ }^{\mathrm{T}}$ matched those of the genus description of Methanoculleus (Boone et al., 1993) and 16S rDNA analysis revealed its phylogenetic relationship to Methanoculleus species.

\section{METHODS}

Media, media preparation and cultivation. Basal media for enrichment cultures and isolation procedures were prepared as previously described (Zellner \& Winter, 1987a). Medium I (Balch et al., 1979), which was modified by omission of yeast extract and peptone (modified medium I) or WHP medium (modified medium I supplemented with $1 \mu \mathrm{M}$ sodium tungstate (WHP medium), was used to cultivate strain INSLUZ ${ }^{\mathrm{T}}$ and reference methanogens (Zellner et al., 1990). All other strains were cultivated in complex medium as previously described (Zellner \& Winter, 1987a). Substrates and additives were added from anaerobic, sterile stock solutions as indicated. Cells were grown on $\mathrm{H}_{2} / \mathrm{CO}_{2}$ $(80: 20, \mathrm{v} / \mathrm{v}, 300 \mathrm{kPa})$ in $120 \mathrm{ml}$ serum bottles on a rotary shaker (150 r.p.m.) at the temperatures indicated. For testing the growth $\mathrm{pH}$ range, the $\mathrm{pH}$ value of the medium was adjusted by addition of $10 \%(\mathrm{v} / \mathrm{v}) \mathrm{HCl}$ prior to inoculation. The $\mathrm{pH}$ increased during growth as a result of consumption of $\mathrm{CO}_{2}$ during methanogenesis. $\mathrm{H}_{2} / \mathrm{CO}_{2}$ was refilled in a fed-batch mode; the produced methane, however, was not replaced. For mass cultivation, cells were grown on $\mathrm{H}_{2} / \mathrm{CO}_{2}$ $(80: 20, \mathrm{v} / \mathrm{v})$ with a flow rate of $501 \mathrm{~h}^{-1}$ in a 121 Biostat $S$ fermenter (B. Braun, Biotech International).

Source and habitat of the isolate. Strain INSLUZ ( = DSM $4273^{\mathrm{T}}$ ) was isolated from a biogas reactor of a palm oil plant on North-Sumatra (Indonesia), which was operated at $55^{\circ} \mathrm{C}$.

Enrichment and isolation of the strain. Despite the operation of the palm-oil-mill effluent-treating digester at $55^{\circ} \mathrm{C}$, no methanogens could be enriched on $\mathrm{H}_{2} / \mathrm{CO}_{2}(80: 20, \mathrm{v} / \mathrm{v})$ in WHP medium ( $\mathrm{pH} 7.0$ ) incubated at $50,60,70$ or $80^{\circ} \mathrm{C}$. However, if incubated at $37^{\circ} \mathrm{C}$, autofluorescent, irregular coccoid methanogens grew on $\mathrm{H}_{2} / \mathrm{CO}_{2}$. This culture was serially diluted into WHP medium and the highest dilution showing growth of the fluorescent, irregularly coccoid strains was again serially diluted and $0.1 \mathrm{ml}$ dilutions were streaked on agar plates with WHP medium plus $2.5 \%(\mathrm{w} / \mathrm{v})$ Oxoid agar (Unipath). All manipulations were performed in an anaerobic chamber (Coy Laboratory Products) under a gas atmosphere of $\mathrm{N}_{2} / \mathrm{H}_{2}(95: 5, \mathrm{v} / \mathrm{v})$. The plates were transferred into a stainless steel anaerobic jar (Balch et al., 1979), pressurized with $300 \mathrm{kPa} \mathrm{H} / \mathrm{CO}_{2}(80: 20, \mathrm{v} / \mathrm{v})$ and incubated at $37^{\circ} \mathrm{C}$. After $20 \mathrm{~d}$ incubation, the gas pressure had reduced to $150 \mathrm{kPa}$ indicating gas consumption. The anaerobic jar was then transferred into the anaerobic chamber, and colonies were picked and injected into $120 \mathrm{ml}$ serum bottles supplied with $20 \mathrm{ml}$ WHP medium under $\mathrm{H}_{2} / \mathrm{CO}_{2}(80: 20, \mathrm{v} / \mathrm{v}, 300 \mathrm{kPa})$ and incubated at $37^{\circ} \mathrm{C}$. This procedure resulted in the isolation of strain INSLUZ ${ }^{\mathrm{T}}$; purity was tested as described previously (Boone \& Whitman, 1988).

Analyses. Volatile fatty acids, alcohols, hydrogen and methane were analysed by GC (Zellner \& Winter, 1987a, c).
Light microscopy. Epifluorescence microscopy of methanogens was carried out as described previously (Zellner et al., 1991).

Electron microscopy and S-layer studies. Micrographs of thin-sectioned or freeze-etched cell preparations were taken on a Philips EM 301 electron microscope at $80 \mathrm{kV}$ and the whole-cell protein pattern of strain INSLUZ ${ }^{\mathrm{T}}$ was analysed by SDS-PAGE with Coomassie blue or periodic acid-Schiff (PAS) staining (Messner \& Sleytr, 1992; Sleytr et al., 1993; Zellner et al., 1989a, b).

Polyamine analysis. The polyamine patterns of the cells were determined after extraction, derivatization with dansyl chloride and separation by HPLC (Zellner \& Kneifel, 1993).

Antigenic fingerprinting. The antigenic fingerprint of strain INSLUZ ${ }^{\mathrm{T}}$ was determined with a panel of antibody $S$-probes of methanogenic reference strains as described previously (Macario \& Conway de Macario, 1983, 1985).

Determination of DNA $\mathbf{G}+\mathbf{C}$ content. The $\mathrm{G}+\mathrm{C}$ content $(\mathrm{mol} \%)$ of strain INSLUZ ${ }^{\mathrm{T}}$ was determined by the thermal denaturation $\left(T_{m}\right)$ method, direct quantification with HPLC (Zellner et al., 1989b), and UV spectroscopy according to the methods of Ulitzur (1972). Isolation and purification of DNA and HPLC determination of the $\mathrm{G}+\mathrm{C}$ content $(\mathrm{mol} \%)$ was performed according to the method of Zellner et al. (1989b). Calf thymus DNA with a $\mathrm{G}+\mathrm{C}$ content of $42 \mathrm{~mol} \%$ was used as a reference for the $T_{m}$ method. The value obtained by UV spectroscopy was calculated from the quotients of the extinctions at different wavelengths $[240 / 280,240 / 275,240 / 270,245 / 280,245 / 275$ and $245 / 270$ (Ulitzur, 1972)]

165 rDNA sequence determination and analysis. Extraction of genomic DNA, PCR-mediated amplification of the $16 \mathrm{~S}$ rDNA, and sequence analysis of the purified PCR products were carried out as described previously (Rainey et al., 1996) and the sequence reaction mixture was electrophoresed using a model 373A automated DNA sequencer (Applied Biosystems). To determine the closest relatives of strain INSLUZ ${ }^{\mathrm{T}}$, its phylogenetic position was analysed using the ARB database (Strunk \& Ludwig, 1995). Fine resolution of relatedness between INSLUZ ${ }^{\mathrm{T}}$ and its closest relatives was performed using the ae2 editor (Maidak et al., 1994). A phylogenetic dendrogram was reconstructed from corrected similarity values (Jukes \& Cantor, 1969) using the treeing algorithm of De Soete (1983). Bootstrap values were determined using the PHYLIP package (Felsenstein, 1993). The accession numbers of the $16 \mathrm{~S}$ rDNAs of reference strains were as follows: Methanoculleus thermophilicus DSM 2373 ${ }^{\mathrm{T}}$, M59129; Methanoculleus marisnigri DSM 1498 ${ }^{\mathrm{T}}$, M59134; Methanoplanus limicola DSM 2279', M59143; Methanomicrobium mobile DSM 1539 ${ }^{\mathrm{T}}$, M59142; Methanogenium organophilum DSM $3569^{\mathrm{T}}$, M59131; Methanogenium cariaci DSM 1497' , M59130; Methanospirillum DSM $864^{\mathrm{T}}$, M60880; and Methanocorpusculum parvum DSM $3823^{\mathrm{T}}$, M59147. The sequences of Methanoculleus bourgensis DSM $3045^{\mathrm{T}}$, Methanoculleus olentangyi DSM $2772^{\mathrm{T}}$, Methanocorpusculum labreanum DSM $4855^{\mathrm{T}}$ and Methanogenium tationis DSM $2702^{\mathrm{T}}$ were obtained from the Ribosomal Database Project (Maidak et al., 1994). The incorrect orthographies of Methanoculleus bourgense and Methanoculleus thermophilicus were, according to Rule 61 of the Bacteriological Code (Lapage et al., 1992), corrected to Methanoculleus bourgensis (corrig.) and Methanoculleus thermophilus (corrig.). 


\section{RESULTS}

\section{Morphology of strains}

Cells of strain INSLUZ ${ }^{\mathrm{T}}$ stained Gram-negative and were highly irregular cocci, $1 \cdot 25-2 \cdot 0 \mu \mathrm{m}$ in diameter. The cells were not seen to be motile but they were flagellated (Fig. 1b).

\section{S-layer lattice}

Addition of $1 \%(\mathrm{w} / \mathrm{v})$ SDS led to lysis of cells of strain INSLUZ ${ }^{\mathrm{T}}$ indicating a cell envelope with a proteinaceous cell wall. The cell envelope of strain INSLUZ ${ }^{\mathrm{T}}$ consisted of a cytoplasmic membrane and an S-layer of hexagonally arranged glycoprotein subunits (Fig. 1a, b). The centre-to-centre spacing of the morphological units of the S-layer lattice was $15.2 \mathrm{~nm}$. The apparent $M_{\mathrm{r}}$ of the glycoprotein subunits, as indicated by a positive PAS staining reaction, was 120000 (Fig. 1c). The S-layer lattice and composition of strain INSLUZ $^{\text {T }}$ were compared with those of the other species of the genus Methanoculleus (Table 1). All irregular Methanoculleus species studied so far possess hexagonal S-layer lattices consisting of glycoprotein subunits with $M_{\mathrm{r}}$ values of $101000-138000$. The $M_{\mathrm{r}}$ of the S-layer glycoprotein of strain INSLUZ ${ }^{\mathrm{T}}$ was within this range.

\section{Antigenic fingerprinting}

The antigenic fingerprint of strain INSLUZ ${ }^{\mathrm{T}}$ was determined with a panel of antibody S-probes for the following reference methanogens (Macario \& Conway de Macario, 1983, 1985): Methanospirillum hungatei $\mathrm{JF} 1^{\mathrm{T}} ;$ Mithanococcus vannielii $\mathrm{SB}^{\mathrm{T}} ;$ Methanococcus voltae $\mathrm{PSv}^{\mathrm{T}}$; Methanoculleus marisnigri JR1 ${ }^{\mathrm{T}}$; Meth-

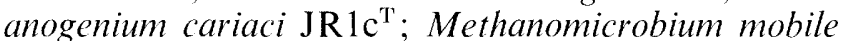
$\mathrm{BP}^{\mathrm{T}} ;$ Methanolobus tindarius $\mathrm{T}^{\mathrm{T}}$; Methanococcus maripaludis $\mathrm{JJ}^{\mathrm{T}}$; Methanoplanus limicola $\mathrm{M} 3^{\mathrm{T}}$; and Methanococcus thermolithotrophicus $\mathrm{SN}^{\mathrm{T}}$. No antigenic relationship between strain INSLUZ ${ }^{\mathrm{T}}$ and any of the methanogenic reference strains, recognized by the antibody S-probes, was detected.

\section{Substrates for growth and methanogenesis}

Growth and methane production of strain INSLUZ ${ }^{\mathrm{T}}$ were only observed with $\mathrm{H}_{2} / \mathrm{CO}_{2}$, formate, 2propanol $/ \mathrm{CO}_{2}$, 2-butanol $/ \mathrm{CO}_{2}$ and cyclopentanol/ $\mathrm{CO}_{2}$ as substrates. Maximal $\mathrm{OD}_{578}$ and methane production levels (per $20 \mathrm{ml}$ modified medium I containing $60 \mathrm{mM}$ acetate and $1 \mu \mathrm{M}$ sodium tungstate obtained in $120 \mathrm{ml}$ serum bottles) were as follows: $\mathrm{H}_{2} / \mathrm{CO}_{2}, \mathrm{OD}_{578} 1 \cdot 00,4187 \mu \mathrm{mol}$ methane; formate, 0.07, $323 \mu \mathrm{mol}$; 2-propanol $/ \mathrm{CO}_{2}, 0 \cdot 15,285 \mu \mathrm{mol} ; 2-$ butanol $/ \mathrm{CO}_{2}, 0.07,120 \mu \mathrm{mol}$; and cyclopentanol/ $\mathrm{CO}_{2}, 0.06,420 \mu \mathrm{mol}$. No stimulation of growth on formate was observed by supplementation with $0.5 \mu \mathrm{M}$ $\mathrm{SeO}_{3}^{2-}\left(\mathrm{OD}_{578} 0 \cdot 06,280 \mu \mathrm{mol}\right.$ methane). Growth of strain INSLUZ ${ }^{\mathrm{T}}$ and methanogenesis were not observed on acetate, methanol, ethanol, 1-propanol, 2pentanol, 2,3-butanediol, dimethylamine or lactate.

\section{Culture conditions}

The optimal growth temperature of strain INSLUZ was about $40^{\circ} \mathrm{C}$ with the shortest doubling time of $13.5 \mathrm{~h}$ (Fig. 2). No growth was obtained below $21^{\circ} \mathrm{C}$ and above $51^{\circ} \mathrm{C}$, despite the fact that the habitat of strain INSLUZ ${ }^{\mathrm{T}}$ was a bioreactor operated at $55^{\circ} \mathrm{C}$.
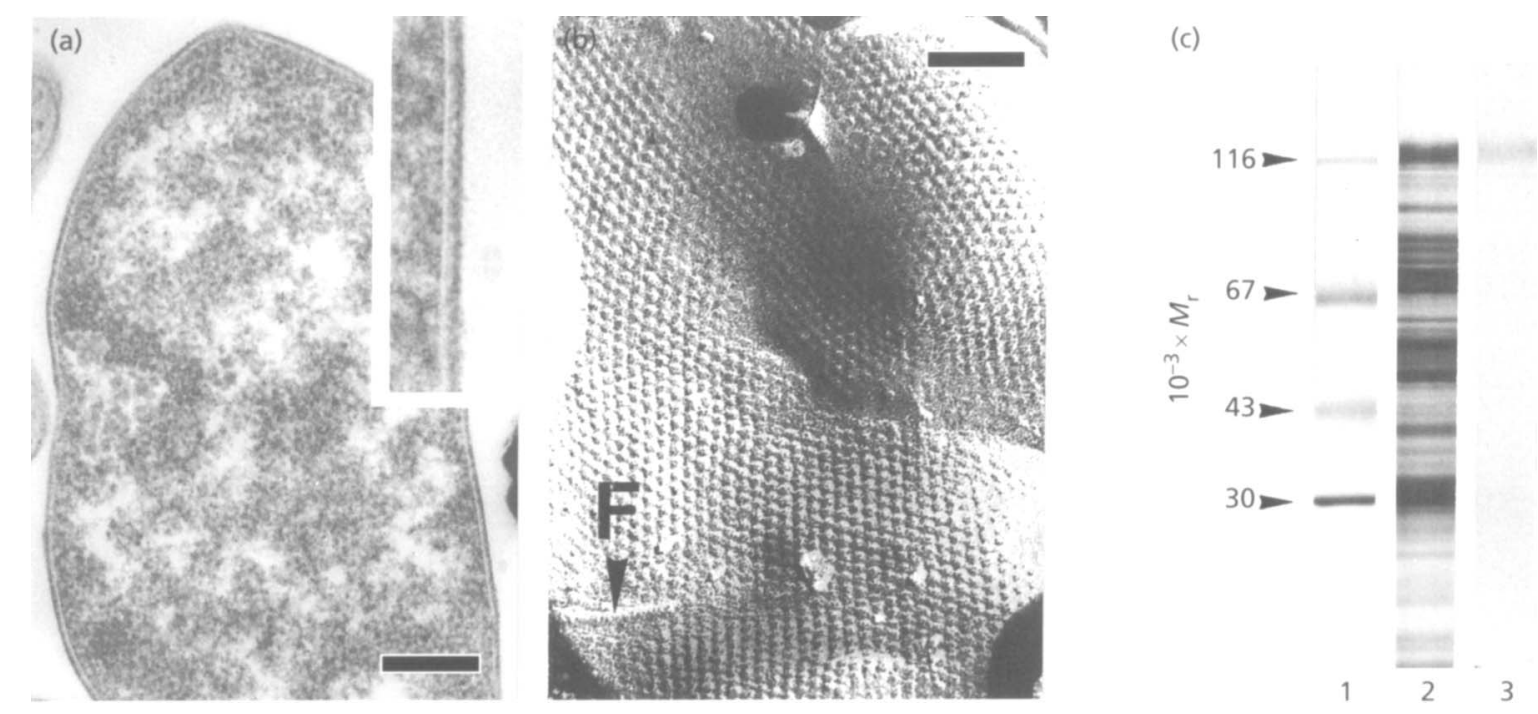

Fig. 1. (a) Electron micrographs of a thin section of a cell of strain INSLUZ ${ }^{\top}$. Bar, $0.1 \mu \mathrm{m}$. (b) Electron micrograph of a freeze-etched preparation of strain INSLUZ ${ }^{\top}$ showing the hexagonal arrangement of the S-layer glycoproteins and a piece of a flagellum (marked F). Bar, $0 \cdot 1 \mu \mathrm{m}$. (c) SDS-PAGE of cell extracts of strain INSLUZ'. Lanes: $1, M_{\mathrm{r}}$ standards; 2 , Coomassie blue-stained; and 3, PAS-stained. 
G. Zellner and others

Table 1. S-layers of species of the genus Methanoculleus

All Methanoculleus strains had hexagonal S-layer architecture and glycoprotein subunits.

\begin{tabular}{|c|c|c|c|c|}
\hline Methanoculleus strain & $\begin{array}{c}\text { DSM } \\
\text { no. }\end{array}$ & $\begin{array}{c}\text { Lattice } \\
\text { constant } \\
(\mathrm{nm})^{*}\end{array}$ & $\begin{array}{c}10^{-3} \times M_{\mathrm{r}} \\
\text { of protein } \\
\text { subunit }\end{array}$ & Reference \\
\hline M. palmolei INSLUZ ${ }^{\mathrm{T}}$ & $4273^{\mathrm{T}}$ & $15 \cdot 2$ & 120 & This study \\
\hline M. marisnigri $\mathrm{JR} 1^{\mathrm{T}}$ & $1498^{\mathrm{T}}$ & ND & 138 & Zellner et al. (1990) \\
\hline M. olentangyi $\mathrm{RC} / \mathrm{ER}^{\mathrm{T}}$ & $2772^{\mathrm{T}}$ & $15 \cdot 4$ & 132 & Zellner et al. (1990) \\
\hline M. bourgensis $\mathrm{MS}^{\mathrm{T}}$ & $3045^{\top}$ & $15 \cdot 4$ & 101 & Zellner et al. (1990) \\
\hline M. thermophilus CR-1 ${ }^{\mathrm{T}}$ & $2373^{\mathrm{T}}$ & ND & 130 & Zabel et al. (1985) \\
\hline M. thermophilus UCLA & 2624 & $\mathrm{ND}$ & 130 & Zabel et al. (1985) \\
\hline M. thermophilus Ratisbona & 2640 & ND & 130 & Zabel et al. (1985) \\
\hline
\end{tabular}

* Centre-to-centre spacing of hexagonally arranged protein subunits of the S-layer. ND, Not determined.

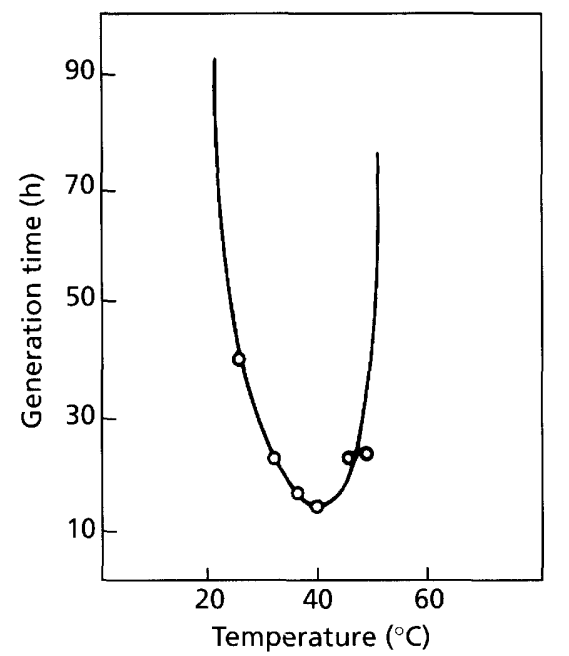

Fig. 2. Effect of temperature on growth of strain INSLUZ ${ }^{\top}$ on $\mathrm{H}_{2} / \mathrm{CO}_{2}$ in WHP medium.

The optimal $\mathrm{pH}$ for growth was $6.9-7.5(\mathrm{pH}$ range 6.5-8.0). Growth of strain INSLUZ ${ }^{\mathrm{T}}$ on $\mathrm{H}_{2} / \mathrm{CO}_{2}$ was slightly promoted by tungstate and potassium ions (not shown).

\section{Polyamines}

Polyamine analysis of strain INSLUZ ${ }^{\mathrm{T}}$ revealed the following polyamine pattern $\left[\mu \mathrm{mol}(\mathrm{g} \text { dry } \mathrm{wt})^{-1}\right]$ : putrescine, 52.64; sym-homospermidine, 11.21; and spermine, 0.03. 1,3-Diaminopropane, norspermidine, spermidine and norspermine were below the detection limit of $0.02 \mu \mathrm{mol}(\mathrm{g} \text { dry wt })^{-1}$.

\section{DNA G + C content}

The $\mathrm{G}+\mathrm{C}$ content of DNA of strain INSLUZ ${ }^{\mathrm{T}}$ was $59.5 \mathrm{~mol} \%$ determined by HPLC (with a standard deviation of three determinations of $\pm 0.1 \mathrm{~mol} \%$ ) and

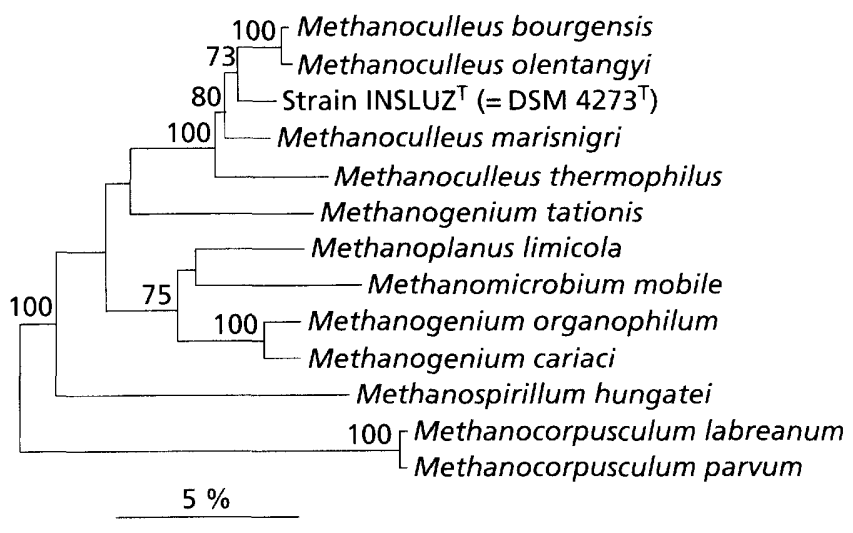

Fig. 3. Dendrogram showing the phylogenetic position of strain INSLUZ ${ }^{\top}$ within the genus Methanoculleus. The sequences of some phylogenetically neighbouring taxa were used to place the genus within the family Methanomicrobiaceae. Bootstrap values (expressed as percentages of 500 replications) of $70 \%$ or more are indicated at the branch points. Bar, $5 \%$ sequence divergence.

$59 \mathrm{~mol} \%$ determined via the thermal denaturation $\left(T_{\mathrm{m}}\right)$ method. The value obtained by UV spectrophotometry was $60 \cdot 0 \mathrm{~mol} \%$.

\section{Phylogenetic analysis}

The almost complete primary structure of the $16 \mathrm{~S}$ rDNA of strain INSLUZ ${ }^{\mathrm{T}}$ was sequenced (1431 nt). The phylogenetic position indicated that strain INSLUZ $^{\mathrm{T}}$ was a member of the genus Methanoculleus. Phylogenetically, strain INSLUZ ${ }^{\mathrm{T}}$ clusters between the species pair Methanoculleus bourgensis DSM 3045 and Methanoculleus olentangyi DSM $2772^{\mathrm{T}},(97.7$ and $97.5 \%$ 16S rDNA similarity, respectively), and Methanoculleus marisnigri $(97.5 \%$ similarity). Methanoculleus thermophilus is slightly less related, showing a range of $16 \mathrm{~S}$ rDNA similarities of $95 \cdot 8-96 \cdot 7 \%$ to the other members of the genus (Fig. 3). 
The degree of similarity of species of Methanoculleus and members of neighbouring genera is significantly lower. ranging between 92 (Methanogenium) and $90 \%$ (Methanoplanus, Methanomicrobium and Methanogenium).

\section{DISCUSSION}

The distinct phylogenetic position of strain INSLUZ within the radiation of Methanoculleus species, based on $16 \mathrm{~S}$ rDNA similarity of less than $97 \%$ with its neighbouring species, is the main argument to propose strain INSLUZ ${ }^{\mathrm{T}}$ as the type strain of a new species in the genus Methanoculleus.

Other differences concerned the architecture of the cell envelope and the antigenic fingerprints. The S-layer composition and architecture of strain INSLUZ ${ }^{\mathrm{T}}$ was in concordance with S-layers found for other species of the genus Methanoculleus (Zellner et al., 1989b, 1990). The $M_{r}$ of the S-layer glycoprotein subunits of strain INSLUZ $Z^{\mathrm{T}}$ was 120000 and distinct from those of any other Me'hanoculleus strain studied so far (101000 and $130000-138000)$, while a much broader range $(90000$ 155000 ) was observed for irregular coccoid methanogens belonging to different genera (Zellner et al., 1989a, b, 1990). The polyamine pattern of strain INSLUZ ${ }^{\prime}$ also resembled that of other Methanoculleus species (Zellner et al., 1990; Blotevogel et al., 1991). The comparison of these and further features, as well as the DNA G+C content (Table 2), support the distinct phylogenetic position of strain INSLUZ ${ }^{\mathrm{T}}$ as a member of a new species of the genus Methanoculleus (Maestroluán et al., 1990).

Studies on the growth-promoting effect of tungstate and influence of medium variations indicated that tungstate could replace the requirement of Methanoculleus palmolei for complex medium components; this was observed for most irregular coccoid strains of the order Mithanomicrobiales (Boone et al., 1993). The growth-promoting effect of tungstate on strain INSLUZ ${ }^{\mathrm{T}}$ was less pronounced, as reported for other hydrogenotrophic methanogens (Zellner \& Winter, 1987b).

The secondary alcohol-oxidizing strain INSLUZ ${ }^{\mathrm{T}}$ contained a secondary alcohol dehydrogenase activity which was dependent on $\mathrm{F}_{420}$. An $\mathrm{F}_{420}$-dependence of the secondary alcohol dehydrogenase activity was also observed for Methanoculleus marisnigri, Methanoculleus bourgensis, Methanogenium liminatans and Methanolacinia paynteri, while Methanocorpusculum or Methanobacterium strains contained an NADP ${ }^{+}$ dependent secondary alcohol dehydrogenase activity (Bleicher et al., 1989).

\section{Description of Methanoculleus palmolei sp. nov.}

Methanoculleus palmolei (palm.o.le'i. L. fem. n. palma palm; L. masc. n. oleum oil; palmolei from oil of the palm; a methane-producing bag-shaped archaeon derived from a bioreactor anaerobically treating palmoil-processing wastewater).

Cells are coccoid methanogens, $1 \cdot 25-2 \mu \mathrm{m}$ in diameter. Acetate is required as growth factor and growth is stimulated by potassium and tungstate ions. Cells are mesophilic and grow optimally at $40{ }^{\circ} \mathrm{C}$ (range 22 $50{ }^{\circ} \mathrm{C}$ ) and at neutral $\mathrm{pH}$ values around $\mathrm{pH} 6 \cdot 9-7.5$ (pH range 6.5-8.0). Cells grow on $\mathrm{H}_{2} / \mathrm{CO}_{2}$, formate, 2propanol $/ \mathrm{CO}_{2}, 2$-butanol $/ \mathrm{CO}_{2}$ and cyclopentanol/ $\mathrm{CO}_{2}$. No growth and no methane production is observed on acetate, methanol, ethanol, 1-propanol, 2pentanol/ $\mathrm{CO}_{2}, 2,3$-butanediol, dimethylamine and lactate. A secondary alcohol dehydrogenase activity, dependent on $\mathrm{F}_{420}$, oxidizes 2-propanol, 2-butanol, 2pentanol and cyclopentanol, but not ethanol, 1propanol, cyclohexanol, 2,3-butanediol or acetoin. The DNA G + C content is $59 \mathrm{~mol} \%\left(T_{\mathrm{m}}\right.$ method $)$ and $59 \cdot 5 \mathrm{~mol} \%$ (HPLC method). Strain INSLUZ ${ }^{\mathrm{T}}$ (= DSM $4273^{\mathrm{T}}$ ) is the type strain.

\section{Table 2. Phenotypic features of the species of the genus Methanoculleus}

Data compiled from literature cited. NR, Not reported.

\begin{tabular}{|c|c|c|c|c|c|c|c|c|}
\hline Methanoculleus strain & DSMI no. & $\begin{array}{c}\text { Cell size } \\
(\mu \mathrm{m})\end{array}$ & $\begin{array}{c}\text { Flagellation } \\
\text { (number)/ } \\
\text { motility }\end{array}$ & Substrate* & $\begin{array}{l}\text { Minimum } \\
\text { doubling } \\
\text { time (h) }\end{array}$ & $\begin{array}{c}\text { Growth temp. } \\
\text { (optimum/ } \\
\text { range; }{ }^{\circ} \mathrm{C} \text { ) }\end{array}$ & $\begin{array}{c}\text { DNA G }+C \\
\text { content } \\
(\mathrm{mol} \%)^{\dagger}\end{array}$ & Reference \\
\hline M. palmmi iNSLI/Z & $4273^{4}$ & 1.252 .0 & $+/-$ & H. F. P. B & 13.5 & $40 / 21 \quad 51$ & $59 \cdot 0^{2}, 59 \cdot 5^{*}$ & This study \\
\hline M. metriveriJR!' & 1498 & 1.3 & $+(N R) /-$ & H. F.P. B & $\mathrm{NR}$ & $20-25 / 10 \cdot 45$ & $61-2^{1}$ & Romesser ef al. (1979) \\
\hline 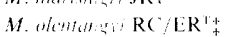 & $2772^{7}$ & 1.01 .5 & $-1-$ & $\mathrm{H}, \mathrm{F},(\mathrm{P}),(\mathrm{B})^{\prime}$ & $10 \cdot 9$ & $37 / 30-45$ & $54 \cdot 4^{1}$ & Corder at al. (1983) \\
\hline M. heserges MS2+t+ & $3045^{1}$ & 1.0) $2 \cdot 0$ & $-/-$ & $\mathrm{H}, \mathrm{F}, \mathrm{P}, \mathrm{B}^{\mathrm{I}}$ & 18.0 & $37 / 25-55$ & $59^{1}$ & Ollivier et al. (1986) \\
\hline 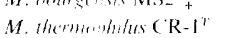 & $2373^{1}$ & $1.0 \quad 1.3$ & $-1-$ & H.F & 2.5 & $55 / 3765$ & $59-60^{\prime} .57-59^{2}$ & Rivard \& Smith (1983) \\
\hline M. thermwher UCLA & 2624 & $0.7-1.8$ & $+(1) / t$ & H. F & 18 & $5560 /<70$ & $56-59 \cdot 7^{2}$ & $\begin{array}{l}\text { Ferguson \& Mah } \\
\text { (1983) }\end{array}$ \\
\hline M. therme thilus Ratisbona & 2640 & $0.9 \cdot 1.5$ & $+(1) /+$ & H. $F^{\prime}$ & $3 \cdot 4$ & $58 / 30-60$ & $57^{2}$ & Zabel et al. (1985) \\
\hline M. thementhilus $\mathrm{TCl}$ & 39) 15 & $0.6-15$ & $\mathrm{NR}$ & H. F. P. B & $\mathrm{NR}$ & $55 / 30 \cdot 60$ & $54 \cdot 7^{2}$ & Widdel et al. (1988) \\
\hline M. oldeningensi $\left.\mathrm{CB}\right|^{\mathrm{T}}$ & $6 \geq 16^{\mathrm{T}}$ & 1.0 & $-1 \ldots$ & II. F & $3-8$ & $45 / 20-50$ & $48 \cdot 6^{2}$ & Blotevogel et al. (1991) \\
\hline
\end{tabular}

$* \mathrm{H}, \mathrm{H}_{.} / \mathrm{CO} ; \mathrm{F}$, formate; P. 2-propanol $/ \mathrm{CO}, \mathrm{B}, 2$-butanol $/ \mathrm{CO}_{2}$. Substrates in parentheses are only weakly utilized. 1, Secondary alcohol utilization tested by Zellner \& Winter (1987c).

† DNA G + C content determined by: I, buoyant density; 2, thermal denaturation; or 3, HPLC.

$\Varangle$ Methano ulleus olentangyi and Methanoculleus bourgensis are apparently subjective synonyms (Xun et al., 1989; Boone et al., 1993). 


\section{ACKNOWLEDGEMENTS}

The authors wish to thank Dr Helmut Kneifel (Jülich, Germany) for analysing the polyamine pattern of strain INSLUZ ${ }^{\mathrm{r}}$, Dr Everly Conway de Macario (Albany, NY) for the antigenic fingerprint, and Anja Hagelstein (DSMZ, Braunschweig. Germany) for growing the cells of strain INSLUZ ${ }^{\mathrm{T}}$ for $16 \mathrm{~S}$ rDNA analysis. We wish to thank Ulrike Mendrock for her help in the molecular work. This investigation was supported in part by grants of the Deutsche Forschungsgemeinschaft. Part of the work described here was carried out at the Institute of Microbiology of the University of Hannover, Hannover, Germany.

\section{REFERENCES}

Balch, W. E., Fox, G. E., Magrum, L. J., Woese, C. R. \& Wolfe, R. S. (1979). Methanogens: reevaluation of a unique biological group. Microbiol Rev 43, 260-296.

Bleicher, K., Zellner, G. \& Winter, J. (1989). Growth of methanogens on cyclopentanol $/ \mathrm{CO}_{2}$ and specificity of alcohol dehydrogenase. FEMS Microbiol Lett 59, 307-312.

Blotevogel, K.-H., Gahl-Janßen, R., Janssen, S., Fischer, U., Pilz, F., Auling, G., Macario, A. J. L. \& Tindall, B. J. (1991). Isolation and characterization of a novel mesophilic, fresh-water methanogen from river sediment Methanoculleus oldenburgensis sp. nov. Arch Microbiol 157, 54-59.

Boone, D. R. \& Whitman, W. B. (1988). Proposal of minimal standards for describing new taxa of methanogenic bacteria. Int $J$ Syst Bacteriol 38, 212-219.

Boone, D. R. \& Xun, L. (1987). Effects of pH, temperature, and nutrients on propionate degradation by a methanogenic enrichment culture. Appl Environ Microbiol 53, 1589-1592.

Boone, D. R., Whitman, W. B. \& Rouvière, P. (1993). Diversity and taxonomy of methanogens. In Methanogenesis: Ecology, Physiology, Biochemistry and Genetics, pp. 35-80. Edited by J. G. Ferry. New York: Chapman \& Hall.

Corder, R. E., Hook, L. A., Larkin, J. M. \& Frea, J. I. (1983). Isolation and characterization of two new methane-producing cocci: Methanogenium olentangyi, sp. nov., and Methanococcus deltae, sp. nov. Arch Microbiol 134, 28-32.

De Soete, G. (1983). A least squares algorithm for fitting additive trees to proximity data. Psychometrika 48, 621-626.

Felsenstein, J. (1993). PHYLIP (phylogenetic inference package) version 3.5.1. Department of Genetics, University of Washington, Seattle, USA

Ferguson, T. J. \& Mah, R. A. (1983). Isolation and characterization of an $\mathrm{H}_{2}$-oxidizing thermophilic methanogen. Appl Environ Microbiol 45, 265-274.

Jukes, T. H. \& Cantor, C. R. (1969). Evolution of protein molecules. In Mammalian Protein Metabolism, pp. 21-132. Edited by H. N. Munro. New York: Academic Press.

Lapage, S. P., Sneath, P. H. A., Lessel, E. F., Skerman, V. B. D. Seeliger, H. P. R. \& Clark, W. A. (editors) (1992). International Code of Nomenclature of Bacteria. (1990 Revision). Washington, DC: American Society for Microbiology.

Ma, A. N. \& Ong, A. S. H. (1986). Palm oil processing - new development in effluent treatment. Water Sci Technol 18, 35-40.

Macario, A. J. L. \& Conway de Macario, E. (1983). Antigenic fingerprinting of methanogenic bacteria with polyclonal antibody probes. Syst Appl Microbiol 4, 451-458.

Macario, A. J. L. \& Conway de Macario, E. (1985). Monoclonal antibodies of predefined molecular specificity for identification and classification of methanogens and for probing their ecological niches. In Monoclonal Antibodies Against Bacteria, pp. 213-247. Orlando, FL: Academic Press.

Maestrojuán, G. M., Boone, D. R., Xun, L., Mah, R. A. \& Zhang, L. (1990). Transfer of Methanogenium bourgense, Methanogenium marisnigri, Methanogenium olentangyi, and Methanogenium thermophilicum to the genus Methanoculleus gen. nov., emendation of Methanoculleus marisnigri and Methanogenium. a description of new strains of Methanoculleus bourgense and Methanoculleus marisnigri. Int J Syst Bacteriol 40, 117-122.

Maidak, B. L., Larsen, N., McCaughey, M. J., Overbeek, R., Olsen, G. J., Fogel, K., Blandy, J. \& Woese, C. R. (1994). The Ribosomal Database Project. Nucleic Acids Res 22, 3485-3487.

Messner, P. \& Sleytr, U. B. (1992). Crystalline bacterial cellsurface layers. Adv Microb Physiol 33, 213-275.

Ollivier, B. M., Mah, R. A., Garcia, J. L. \& Robinson, R. (1985). Isolation and characterization of Methanogenium aggregans sp. nov. Int J Syst Bacteriol 35, 127-130.

Ollivier, B. M., Mah, R. A., Garcia, J. L. \& Boone, D. R. (1986). Isolation and characterization of Methanogenium bourgense sp. nov. Int $J$ Syst Bacteriol 36, 297-301.

Rainey, F. A., Ward-Rainey, N., Kroppenstedt, R. M. \& Stackebrandt, E. (1996). The genus Nocardiopsis represents a phylogenetically coherent taxon and a distinct actinomycete lineage: proposal of Nocardiopsaceae fam. nov. Int $J$ Syst Bacteriol 46, 1088-1092.

Raskin, L., Poulsen, L. K., Noguera, D. R., Rittman, B. E. \& Stahl, D. A. (1994). Quantification of methanogenic groups in anaerobic biological reactors by oligonucleotide probe hybridisation. Appl Environ Microbiol 60, 1241-1248.

Rivard, C. J. \& Smith, P. H. (1983). Isolation and characterization of a thermophilic marine methanogenic bacterium, Methanogenium thermophilicum sp. nov. Int J Sist Bacteriol 32, 430-436.

Romesser, J. A., Wolfe, R. S., Mayer, F., Spiess, E. \& WaltherMauruschat, A. (1979). Methanogenium, a genus of marine methanogenic bacteria and characterization of Methanogenium cariaci spec. nov. and Methanogenium marisnigri spec. nov. Arch Microbiol 121, 147-153.

Schnürer, A., Houwen, F. P. \& Svensson, B. H. (1994). Mesophilic syntrophic acetate oxidation during methane formation by a triculture at high ammonium concentration. Arch Microbiol 162, 70-74.

Sleytr, U. B., Messner, P., Pum, D. \& Sára, M. (1993). Crystalline bacterial cell surface layers. Mol Microbiol 10, 911-916.

Strunk, O. \& Ludwig, W. (1995). ARB - a software environment for sequence data. Department of Microbiology, Technical University of Munich, Munich, Germany.

Ulitzur, S. (1972). Rapid determination of DNA base composition by ultraviolet spectroscopy. Biochim Biophys Acta 272. $1-11$.

Widdel, F., Rouvière, P. E. \& Wolfe, R. S. (1988). Classification of secondary alcohol-utilizing methanogens including a new thermophilic isolate. Arch Microbiol 150, 477-481.

Xun, L., Boone, D. R. \& Mah, R. A. (1989). Deoxyribonucleic acid hybridization study of Methanogenium and Methanocorpusculum species, emendation of the genus Methanocorpusculum, and transfer of Methanogenium aggregans to the genus Methanocorpusculum as Methanocorpusculum aggregans comb. nov. Int J Syst Bacteriol 39, 109-111.

Zabel, H. P., König, H. \& Winter, J. (1985). Emended description of Methanogenium thermophilicum, Rivard and Smith, and 
assignment of new isolates to this species. Syst Appl Microbiol 6 , $72-78$.

Zellner, G. \& Kneifel, H. (1993). Caldopentamine and caldohexamine in cells of Thermotoga species, a possible adaptation to the growth at high temperatures. Arch Microbiol 159, $472-476$.

Zellner, G. \& Winter, J. (1987a). Analysis of a highly efficient methanogenic consortium producing biogas from whey. Syst Appl Microbiol 9, 284-292.

Zellner, G. \& Winter, J. (1987b). Growth promoting effect of tungsten on methanogens and incorporation of tungsten-185 into cells. FEMS Microbiol Lett 40, 81-87.

Zellner, G. \& Winter, J. (1987c). Secondary alcohols as hydrogen donors for $\mathrm{CO}$,-reduction by methanogens. FEMS Microbiol Lett 44, 323-328.

Zellner, G., Vogel, P., Kneifel, H. \& Winter, J. (1987). Anaerobic digestion of whey and whey permeate with suspended and immobilized complex and defined consortia. Appl Microbiol Biotechnol 27, 306-314.

Zellner, G., Messner, P., Kneifel, H., Tindall, B. J., Winter, J. \&
Stackebrandt, E. (1989a). Methanolacinia gen. nov., incorporating Methanomicrobium paynteri as Methanolacinia paynteri comb. nov. J Gen Appl Microbiol 35, 185-202.

Zellner, G., Stackebrandt, E., Messner, P., Tindall, B. J., Conway de Macario, E., Kneifel, H., Sleytr, U. B. \& Winter, J. (1989b). Methanocorpusculaceae fam. nov., represented by Methanocorpusculum parvum, Methanocorpusculum sinense spec. nov. and Methanocorpusculum bavaricum spec. nov. Arch Microbiol 151, 381-390.

Zellner, G., Sleytr, U. B., Messner, P., Kneifel, H. \& Winter, J. (1990). Methanogenium liminatans spec. nov., a new coccoid, mesophilic methanogen able to oxidize secondary alcohols. Arch Microbiol 153, 287-293.

Zellner, G., Geveke, M., Conway de Macario, E. \& Diekmann, H. (1991). Population dynamics of biofilm development during start-up of a butyrate degrading fluidized-bed reactor. Appl Microbiol Biotechnol 36, 404-409.

Zellner, G., Macario, A. J. L. \& Conway de Macario, E. (1997). A study of three anaerobic methanogenic bioreactors reveals that syntrophs are diverse and different from reference organisms. FEMS Microbiol Ecol 22, 295-301. 
